Balance of US energy research attacked

Advisory group

\section{gives comfort to}

\section{Reagan's foes}

Washington

A top level advisory committee to the US Department of Energy (DoE) has told the Reagan Administration politely but firmly that it is not making the best use of its resources for energy research. In particular, the committee says that there is insufficient support for conservation technologies and that too much is being spent on nuclear energy.

The report was published shortly before President Reagan's announcement last week that he is soon to submit plans to Congress for dismantling DoE. He said that the purpose of the move is to create "a strong federal effort in basic research in energy that avoids excessive regulation".

The centrepiece of the reorganization is a new Energy Research and Technology Administration within the Department of Commerce. The plan is expected to meet fierce opposition in Congress, particularly from those who favour an independent energy research agency on the grounds that close links with the Commerce Department would reinforce the alleged pro-nuclear bias.

The criticisms of present energy research policies came from DoE's Energy Research Advisory Board (ERAB), an independent, non-partisan group. The chairman of the board is $\mathrm{Mr}$ Louis $\mathrm{H}$. Roddis Jr, previously president of Consolidated Edison of New York, and the report was prepared at short notice at the request of DoE by a panel, led by Dr John S. Foster, vice-president for science and technology at TRW Inc., comprising all ERAB members and several outside consultants.

Objections to the Reagan plan are already coming from another direction, namely congressmen unhappy at the proposal that the nuclear weapons research carried out at the nation's weapons laboratories should be among the activities transferred to the Department of Commerce. Speaking at the National Press Club in Washington last week, commerce secretary S. Malcolm Balrige said that his department's experience with other research agencies, such as the National Oceanic and Atmospheric Administration, made it a natural place for locating energy research. He also admitted that the Commerce Department's responsibility to assist in increasing exports could logically include the international promotion of American nuclear technology.

The ERAB report takes as its frame of reference the policy guidelines laid down by the Reagan Administration, thereby insulating itself from the criticism that it is making a political attack on Mr Reagan's policies. Although in principle enthusiastic about the new policy directions, the ERAB committee is concerned about how decisions, such as the cutting back of research funds for conservation and solar technology, have turned out in practice. And the report champions higher energy prices as the best way of encouraging efficient use of energy and utilization of new energy sources.

All 20 members of the committee agreed on the need to emphasize new energy technologies where research has already reached the stage at which the results could, if desired, be directly taken over by the private sector, and should otherwise be dropped if this desire does not exist. For example, the report recommends the elimination of support for research into small-scale hydropower and magnetohydrodynamics (decisions already made by the Reagan Administration), and a sharp reduction in support for research on electric vehicles.

Little change is advocated for most of the basic sciences whose budgets are the current responsibility of the department, including high energy physics and nuclear physics, and which would be incorporated directly into the new agency. And the board favours greater support for efforts aimed at improving the quality and quantity of scientific personnel at US universities in energy-related areas, described as an area "appropriate for federal concern" but currently receiving only $\$ 10.6$ million a year.

The most controversial parts of the report are those which address directly the government's role in supporting research into the generation of electricity through nuclear power. The ERAB report describes the Clinch River fast breeder reactor as being "not an urgent priority", recommending that, under current budget constraints, such a demonstration project should be postponed. Four members of the advisory board, however, dissent from this opinion on the grounds that not proceeding with the construction phase of the fast reactor would mean writing off the $\$ 1$ billion that has been invested so far, and

\title{
What case for building Clinch River?
}

\section{Washington}

Following Congress's decision last month to give the go-ahead for the construction of the liquid metal fast breeder reactor at Clinch River in Tennessee, the focus of the controversy surrounding the project has shifted back to the Nuclear Regulatory Commission (NRC), which would have to issue a permit allowing the construction to proceed.

Last week, the five members of the commission agreed to consider a request from the Department of Energy that it be given "emergency" exemption from conventional licensing procedures. According to Energy Secretary James Edwards, such an exemption is necessary to avoid the " undue hardship" which, he told NRC, would result from further hold-up in the long-delayed construction plans.

Critics of the reactor, however, claim that the Department of Energy is trying to manoeuvre NRC into providing a provisional construction licence as soon as possible so as to pre-empt further attempts by Congress to terminate the project. The critics claim that their case is substantiated by an internal Department of Energy memorandum, released last week by the Natural Resources Defense Council (NRDC), in which Under-Secretary of Energy Guy Fiske suggests that the request for an emergency exemption from NRC be withheld until the 1982 appropriation bill is passed - an amendment could have been added forbidding the Department of Energy from making such a request - and that the Council on Environment Quality be asked about securing "strong support" for an internal environmental report establishing the "negligible environmental impact" of the construction of the reactor.

NRDC attorney Barbara Finamore said that the memo "reveals a calculated effort by the Department of Energy to undermine the integrity of the NRC and its licensing process". Supporters of the fast reactor, that the Clinch River project is needed to demonstrate this technology in the US licensing and safety environment.

Although the construction of the Clinch River reactor has been approved by Congress, its completion is not certain. It is generally accepted in Washington that the main reason for Congress's approval was political - the project is strongly backed by Tennessee Senator Howard Baker Jr, the leader of the Senate.

One possible outcome is that preliminary construction work will be carried out, partly to satisfy the pro-nuclear supporters in Congress to whom the fast reactor has become an important symbol, but that eventually even the utility companies which now back the project will agree that it is inappropriate to continue, and the Clinch River reactor will be abandoned on the grounds of its inefficiency and antiquity.

David Dickson 